\title{
Parental Expectations and Young People's Migratory Experiences in Indonesia
}

\author{
Wenty Marina Minza ${ }^{1}$ \\ Center for Indigenous and Cultural Psychology \\ Faculty of Psychology Universitas Gadjah Mada
}

\begin{abstract}
Based on a one-year qualitative study, this paper examines the migratory aspirations and experiences of non-Chinese young people in Pontianak, West Kalimantan, Indonesia. It is based on two main questions of migration in the context of young people's education to work transition: 1) How do young people in provincial cities perceive processes of migration? 2) What is the role of intergenerational relations in realizing these aspirations? This paper will describe the various strategies young people employ to realize their dreams of obtaining education in Java, the decisions made by those who fail to do so, and the choices made by migrants after the completion of their education in Java. It will contribute to a body of knowledge on young people's education to work transitions and how inter-generational dynamics play out in that process.
\end{abstract}

Keywords: intergenerational relation; migratory aspiration; youth

Internal migration plays a key role in mapping mobility patterns among young people, as many young people continue to migrate within their home country (Argent \& Walmsley, 2008). Indonesia is no exception. The highest participation of rural urban migration in Indonesia is among young people under the age of 29 , mostly for the purpose of education or work (Effendi, 2015).

Based on a one-year qualitative study, this paper will focus on how (non-Chinese) young people from a provincial city in Indonesia, Pontianak, West Kalimantan, view migration and the inter-generational processes involved in realising their aspiration to migrate and their decisions to return. Migration in the Pontianak context is related with its position as a peripheral location within Indonesia and its relations to mainland Java. Both the younger and

\footnotetext{
${ }^{1}$ Address for corespondence: wminza@ugm.ac.id
}

older generation in Pontianak generally associate Java with ideas of progress, opportunities for social mobility, and the success of inter-generational reproduction or regeneration. Yet, migration involves various negotiation processes that go beyond an analysis of push and pull factors. Apart from the idea that having studied in Java provides leverage to compete in the local labour market in West Kalimantan, migration also provides a pathway to adulthood. On the one hand, young people often view migration as associated with a life phase parallel to home-leaving in 'Western' cultures. It involves the idea of independency from parents and thus, an indicator of their transition to adulthood. Yet, parents are not always supportive of their children leaving their home. Preferring their children to stay nearby, even though their children have to face lost opportunities from obtaining 
education in Java. For some parents, independency is only half the story of the transition to adulthood. The other half of becoming an adult in parents' eyes is to build an interdependent relationship, especially in the realm of caring and providing intergenerational (financial) support. Thus, a majority of Pontianak's youth eventually return to Pontianak after completing school to fulfil their parents' expectations in reproducing interdependent relations with the family.

\section{Ethnicity and periphery: Contextualizing West Kalimantan and Pontianak}

Young people's lives in West Kalimantan, and Pontianak in particular, are structured by the ethnic history of the region. Ethnicity, often going hand in hand with religion, often influences young people's educational choices and their outlook on migration for furthering their education, which further details will be shown in this paper. West Kalimantan is inhabited by a multi-ethnic society, with four main ethnic groups: Dayak, Malay, Chinese, and Madurese. The Dayaks and Malays are considered the original inhabitants of the province, even though the Malays are actually Arab migrants arriving around the 1700 's and introduced Islam to the region (Government of Pontianak, 2009). The Malays are often associated with Islam and Dayaks with Christianity. The Chinese arrived in West Kalimantan between the $18^{\text {th }}$ and $19^{\text {th }}$ centuries (Heidhues, 2003), arriving in the northern part of West Kalimantan, around the same time as the Malays. The Chinese are currently the major players in Pontianak's economy, most are either Buddhist or Confucian. The Madurese arrived last to West Kalimantan, and migrated from the island of Madura, East Java, around the early 20th century as low skilled workers for the Malays
(Sudagung, 2001). The Madurese are Muslims, like the Malays. While Muslims from other ethnic groups are considered Malay, Madurese religious and cultural practices created a Madurese identity separate from Malay.

The Malay are assumed to be more educated, urbanised, and of higher social status than the Dayaks. Conversely, the Dayaks are assumed to come from rural areas, and to be of lower status than the Malays. The Chinese are viewed to have high economic social standing and 'exclusive'. The Madurese are viewed as uneducated, violent, and come from poor economic backgrounds. These stereotypes structure the ways young people view and strategize for their future, as opportunities are often framed within ethnic boundaries (Minza, 2014). In some cases, these stereotypes reflect the historical marginalisation and opportunities available for certain ethnic groups to gain their current positioning in society. The Madurese's already low social economic status as low skilled migrant workers has exacerbated the marginalisation of this ethnic group, as the Madurese have to deal with their defeat in one of the violent ethnic conflicts in the West Kalimantan's history. The Dayaks position as ulun or slaves for Malay kingdoms during Dutch rule has limited their opportunities for social mobility across generations, while securing advantageous positions for the Malays (Tangkilisan, 2005).

Pontianak is inhabited by 527.102 people in 2009 (Pontianak Regional Development Agency, 2015), the majority being Chinese and Malay, followed by other ethnic groups (Government of Pontianak, 2009). Pontianak's position as the provincial capital of West Kalimantan frames young people's outlook towards out-migration to Java. The introduction of 
decentralisation was assumed to bring further development, particularly in regions outside of Java. In Pontianak, decentralisation has accelerated development of local infrastructure, communication, and transportation facilities. Pontianak is better connected with other district towns and bigger cities. Investment opportunities have boosted the economy.

In the past years, the highest contributor to economic growth in Pontianak is the trade, hotel and restaurant sector (Pontianak Statistics Bureau, 2008; Regional Development Agency, 2015), providing mostly low skilled job opportunities for young people in the city. This stands in rather contrast to the rapid increase of tertiary education facilities between 1998 and 2008 (Pontianak Statistics Bureau, 1998; 2008), raising young people and their family's aspirations of obtaining respectable jobs in the civil service.

However, being better connected to bigger cities also means that people in Pontianak have become more aware of their limitations. Despite decentralisation's contribution on accelerating development and progress in many regions outside of Java (Cameron, 2003), the gap between Java and the outer islands remains. The outer islands have not been able to catch up with development in Java, as reflected by the fact that the ten poorest provinces in 2009 are located in the outer islands (Central Bureau of Statistics, 2010). In Pontianak, both parents and young people in Pontianak are equally aware of the limited qualified universities existing in Pontianak, despite the rapid increase of higher education facilities in the recent years. One of the options in securing a better future for young people is to obtain better quality education in Java and return to compete in the local labour market. As such, most
Pontianak youth view migration to Java or to other places as a temporary move.

\section{Intergenerational relations}

Mannheim (1952) stated that the concept of generation is linked to the concept of social and cultural reproduction through intergenerational relations. In intergenerational relations, the process of cultural transmission that facilitates the occurrence of social reproduction is often accompanied by a process of adaptation and negotiation by the younger generation. This idea is also supported by Mathews and White (2004) who argued that no matter how much social change young people face, they are socialised by the values and practices of the older generation. However, which values and practices are reproduced, how, and to what extent, is largely a matter of agency on the part of young people. Adaptation and negotiation in cultural transmission includes looking at how each generation conceptualises the meaning of and experience of migration, within the changing political, social and economic conditions they face (Wyn and Woodman, 2006).

Migrating is not an individual decision, nor is it merely structured by the family. In 'Western societies', family, friends, and community play a role in whether or not a young person moves (Dette \& Dalbert, 2005). For young people in these 'Western' societies, home leaving becomes an important rite of passage to adulthood (Seiffge-Krenke, 2009), where parents play an important role to ensure that the normative timing of home leaving is reproduced. Parents usually expect their children to leave home once they are legally considered as an adult. Late home leavers are seen to have less autonomy and lacking the intention to become an adult (Kins et al., 2009). "Boomerang children", children who 
return to their parental home after leaving home, are seen as failures or in a limbo (Davidson, 2014). On the other hand, migration in Asian families is often seen as part of family obligations where individual agency is often overlooked. Asis (2002) argues that migration in Asian families does not necessarily mean that individual desires always submit to family expectations and obligations, rather, they are interwoven in family projects.

The concept of generation recognises the existence of asymmetrical power relations between youth and adults, where youth are often positioned as subordinate, powerless, and marginal in relation to adults. Though young people possess the agency to strategize in situations where intergenerational conflict occurs, they often have to find rather subtle ways to resist. These subtle ways include focusing on intra-generational relations, which includes spending time and relying more on friends or peer networks to achieve their goals (Jeffrey, 2010), using technology such as mobile phones to extend parental curfew (Williams \& Williams, 2005), or engaging in various youth cultures of resistance (Leksana, 2009).

\section{Methods}

This research was conducted using one a year qualitative study. It used in-depth interviews as its main method which enabled capturing migration as a process, where intergenerational relations are an essential part of that process. The interviews facilitated an understanding of these relations through the subjective lens of young people, and to a certain extent, their parents. The main study interviewed 106 young people from four main ethnic groups in West Kalimantan, with a relative balance between young women and young men. Twelve parents were also interviewed to obtain an idea of the views and expectations they have for their children.

For the purpose of this paper, the migratory experiences of two young people will be intensively discussed, both of which are narratives of non-Chinese youth (a Madurese young man and a Dayak young woman), who have finished their studies in Yogyakarta, Java. Chinese youth have quite a different view and experience of migration than their non-Chinese counterparts in West Kalimantan. Thus, their experiences are more suitable to elaborate in a separate paper. Interviews from three other young people and two parents are included to support the argument in this paper.

The stories of the two young people in this paper have been chosen based on the rather extreme differences in their migratory experiences and the different genders and ethnicity they represent. At the same time, the two cases represent the challenges and negotiation processes that young people in a provincial town such as Pontianak generally have to face to fulfil family expectations and fulfil their own individual aspirations.

\section{Result}

\section{Negotiating migration}

In general, Pontianak young people have quite high aspirations on migrating, especially to Java. As I have explained elsewhere (Minza, 2012), an exception applies for Chinese youth, who generally aspire to migrate to Jakarta and Australia. Non-Chinese youth (in this case Malay, Dayak and Madurese youth), are not necessarily supported by their parents in realising their aspirations to migrate, as expressed by Yayan (45), a Malay man and teacher at one of the state elementary 
schools in Pontianak. He is a father of a 20year-old son who is attending a private university in Pontianak.

"I do not have the courage to send my son to further his education outside of Pontianak, he is not mature enough to go. So, I encouraged him to stay here. When he is here, I can observe his schooling and his psychological development. If one day he is ready to leave Pontianak, I will let him migrate to Java. We all know that the quality of education there is better and promising, because there is a difference between alumni of Java universities and those from Pontianak. I have seen for myself how the community in Jogja (short for Yogyakarta) support learning, as not many young people are seen hanging out until late at night at intersections or on the streets."

Yayan's attitude towards migration is common among parents in Pontianak. Despite knowing that Java offers better quality education than Pontianak, they express various reasons and concerns about having their children migrate to Java. Like Yayan, many parents point to their children's lack of maturity to leave home, fearing that migration will bring negative influences to their children. In other cases, children stay behind to take care of a sick parent, which is viewed as a family obligation they have to submit to. Rabe'ah (50) a Malay mother explained that her husband had a stroke recently and is in therapy. He would need someone to take him to his therapy sessions and to the doctor to monitor his progress while she is at work, teaching at an elementary school in Northern Pontianak. She expected that her 18-year-old daughter, Arum, would

\footnotetext{
2 Pontianak City and Pontianak District are two
} different administrative regions. In this paper, take on the responsibility of caring for her father. Arum eventually buried her dreams of studying in Java and decided to major in nursing at a local academy to be close to her parents. Being the only daughter in the family, Arum is expected to be involved in caring for parents rather than her older brother. Arum's case shows that morality issues are a strong basis that young people consider when finally deciding to submit to their parents' expectation to stay in Pontianak.

Young people negotiating their way to migrate to Java tend to submit to their parents' wishes to stay behind when both parents object to the idea of migrating. Having the support of at least one parent improves a young person's bargaining power to leave as I will show in the following cases. Tri (24), is a Dayak young woman from the District of Pontianak, around an hour drive from Pontianak ${ }^{2}$. Her first move from home was when she commenced high school in Pontianak. Her parents encouraged her to go to Pontianak, because they wanted Tri to have a better education in the city. As teachers, both her parents understood the importance of acquiring quality education in the provincial capital. In the end of her senior year in high school, Tri decided that she wanted to pursue a career as a pharmacist. She started to search for information on pharmacy programs offered in Pontianak when she graduated in 2001.

At that time, the state university in Pontianak did not have a Pharmacy department or faculty. Thus, she had to choose from private tertiary education institutions. Akfar Yarsi (Akademi Farmasi Yayasan Rumah Sakit Islam) was the only tertiary education institution she knew she could access. This Islamic based academy

Pontianak City, the provincial capital is referred to as solely Pontianak. 
did not correspond to the principle of this Catholic young woman, as female students attending the academy are obliged to wear a headscarf. As she always remembers her parents' advice to keep her religious principles, she decides to look into tertiary education institutions in Java, Yogyakarta and Jakarta being the first places she thought of.

Tri has an uncle who has already resided in Jakarta, and in Yogyakarta, she has cousins who are also continuing their education there. She says that she decided to go to Yogyakarta because she was unfamiliar to big city life, specifically pointing to the heavy traffic jams she would have to face in Jakarta, and her peer network in Yogyakarta was stronger than in Jakarta. Yet, before her departure to Yogyakarta, she had to deal with the fact that her mother was unwilling to let her go to Java. Her mother was worried that Tri will not be able to have a comfortable life in Java. Tri did not confront her mother. Without her asking, her father finally influenced her mother to allow her departure to Java. He reminded her mother of the religious principle that Tri was basing her decision upon, which is "not selling her religion". In fact, Tri remembers that her father was rather strict about this matter and her mother eventually gave in.

Tri is not alone in having to struggle to obtain consent from her mother to migrate to Java. While Tri's father was successful in persuading her mother, not all cases show that fathers always have the last say in their children's migratory decisions. Arjan's story is an example of youth resistance that is less subtle and rather direct. Arjan is a 30year-old Madurese young man who

\footnotetext{
3 The Sambas conflict is one of the largest ethnic conflicts in the history of West Kalimantan that involved the Malays and the Madurese in the District of Sambas (the Northern coastal region of
}

migrated to Malaysia after the Sambas conflict in 19993. He is a 30-year-old Madurese young man, whose life was directly affected by the Sambas conflict. Like many Madurese of the older generation who have relatively low educational backgrounds, Arjan's parents only experienced schooling at the elementary school level. His father did not even graduate from elementary school. His family was evicted from the district of Sambas, along with many other Madurese families. They left from Pontianak without bringing any of their valuables, but through their small trade activity, his parents managed to progress him through high school.

It was after finishing high school that he left for Malaysia to become a construction worker for 9 months. His mind was set on saving money from his job in Malaysia to study at a university in Java. Arjan's intention of obtaining tertiary education in Java was final, despite his mother disagreeing with his decision to continue his tertiary education in Java.

"My father asked 'does your mother know'. I replied that she doesn't. I only told my mother the afternoon before I departed. Perhaps my father had informed her. I said to my mother 'Mak (mom), I am going off to university. I really want to go to Jogja, and I need your blessing'. My mom was silent, she did not say anything, not a yes, not a no. Pure silence. My father strengthened me by saying 'you just go, it will be all right'. So, I left".

Reflecting on his past decision to migrate without his mother's consent,

West Kalimantan). It has resulted in forced evacuation of the Madurese to Pontianak, Arjan being one of the survivors of the ethnic conflict. 
Arjan regrets of the strategy he imposed upon his mother to realise his intentions of studying in Java. But he knows that if he had cancelled his plans on departing to Java, he would regret his decision for all his life.

Migration: The path to independency and adulthood

Mandiri is the local term used to indicate independency. Independency usually refers to financial independency, the capacity to make decisions without the support of an adult family member, and sticking to one's own value in the process of decision making. Migration is generally a strategy to achieve this kind of independency. However, in some cases parents often arrange for their children to stay with a family who have already migrated at the place of destination. Because of this, some youth feel that they have not really succeeded in breaking away from family structures, and become independent. This was quite clear in Tri's case where she proudly described her departure to Yogyakarta was not arranged by her parents. She relied on her own network, a Dayak network, initially introduced by her cousin who was already studying in Yogyakarta. This ethnic network was well structured to prepare new comers to start their studies. They have established a group of tutors who would be responsible in providing lessons to new Dayak high school graduates from Pontianak who intended to register at a university there.

Tri's description of her arrival in Yogyakarta clearly shows the importance of ethnic networks for young people in Pontianak who may be away from parents for the first time. Selecting and registering to a new university is also not an easy task for young first time migrants. Making significant decisions that will influence their lives in the future can be a frustrating situation. To have a group of people provide information and guidance lessens young people's distress during this process. As young people become more skilled in making their own decisions, they often feel a sense of having more control over their lives. This newly found independency to decide what and which university she wanted to study was quite liberating for Tri, as she found more opportunities to make her own decisions when she is far away from her parents.

Tri also expresses the importance of learning to develop a sense of control, which she believes will facilitate a person in achieving his/her goals. She referred to her cousin, a senior student at an Engineering Faculty at the Catholic university, as her mentor in shaping her sense of self control. Before she was accepted at a university in Yogyakarta, she had to negotiate her activities with her cousin, even if it was only for purposes such as going to the mall. She felt that this training process was worthwhile. It avoided her from misleading parents and families back home, who are convinced that she is studying hard to acquire good quality education in Java. Tri explained that sometimes even the existence of networks that help prepare young people in studying in Jogja, fail at facilitating them to enter good universities.

"I know friends who came to Jogja to study, and their parents have spent a whole lot of money to support their study. But they are either unfortunate or lack the motivation to prepare themselves to enter a good university in Yogyakarta. So, they basically come to Jogja for nothing, it is just for the prestige. In reality, the quality of education they receive is the same as in Pontianak. One of my relatives went to 
these low-quality universities in Jogja. The university shut down in the middle of her studies, and this really made her quite depressed. She decided to go back to Pontianak without ever finishing university".

Independency through migration was also important for Arjan. However, his migration path to seek further education opportunities in Java was more challenging. Unlike Tri who had the opportunity of obtaining information about various choices of university from her seniors, all Arjan held on to was information about the West Kalimantan boarding home in Yogyakarta and a small brochure containing advertisements about a tertiary education institution in Yogyakarta when he left Pontianak. He left Pontianak, only to find out that, at the end, it was only an institution providing computer courses. His limited knowledge of what campus life is like, inhibited him from being suspicious of this institution from the beginning. After following some of his friends on their campus, he realised that the education system at his campus was not the same as that of his friends. That was when he and other students knew they were misled by this institution. They filed a collective law suit against the institution, won, and had the institution closed. To Arjan's disappointment, it re-opened again a year later.

Interdependent relationships: The full circle to adulthood

Young people generally state that their return to Pontianak is based on their mothers' wishes, as expressed by Aam (26),

\footnotetext{
${ }^{4}$ D1, D2, D3 is a one-year, two-year, and three-year non-degree diploma program in applied sciences, respectively.
}

a Malay young man from Putussibau, 18 hours from West Kalimantan by land.

"If I were to choose between staying in Jogja or returning to Pontianak, I would choose to live in Jogja. Everything is cheap there, I have already worked there for 1 year. I was hired as an elementary school teacher. I came back to Pontianak because my mother asked me to return to West Kalimantan. I felt sorry for my parents, as they perceive Jogja as being too far from Putussibau. If something happens to one of them, they are afraid I would not be able to reach them in time. Pontianak is closer to Putussibau".

Arjan on the other hand, expressed his father's influence on his decision to return to Pontianak. Arjan put himself through a course to enter university with left over money he brought from Malaysia. He spent four million rupiah (around 300 US dollars) for the course and eventually succeeded in entering one of the qualified private tertiary education institutions for accountancy in Yogyakarta.

"I said to myself that I had to get a diploma, even if it is only a D1, D2, D34. I went around Yogyakarta, from one campus to another, searching a qualified campus I could afford. I finally found a tertiary educational institution for accountancy which offered a D2 program. I considered that when I find more money, I will continue to the D3 program. I worked in various jobs, mostly in computer rentals, or selling newspapers to save money to continue my education. I was also lucky to receive a scholarship and 
finally got my D3 diploma. I was ready to return to Pontianak when my father insisted that I continue my education to a full four-year undergraduate program. He said, 'If you become unemployed when you return, it would be better to have finished S1"5.

Arjan continued, stating that his father asked him to continue to a full four-year undergraduate program. Arjan understood by then that despite his parents' low educational background, they were realistic in their expectations towards him. Learning from others' experiences, his parents understood that an S1 diploma would not guarantee obtaining an office job. Before, he was terrified that if he insisted on continuing his studies to S1 and returned unemployed, his parents would be much more ashamed of him in comparison to him only being a D3 graduate. Since proper jobs in Pontianak require an S1, being a D3 graduate gave him the perfect excuse for being unemployed. On the contrary, being an unemployed S1 graduate gives the impression of individual failure, which extends to family honor. Eventually, he continued his S1 with a scholarship he received from the same campus.

After graduating, Arjan intended to find a job in Yogyakarta. However, his parents insisted that he return to help the family develop their small business in one of the poorest sub districts in Pontianak. A demand that he submitted to. When I visited him, Arjan has already succeeded in expanding the family business, managing to establish a small canteen and a computer rental business. He proved his independency by migrating, but realises that the full notion of becoming an adult is by fulfilling his parents' expectations strengthening the family business. For him, this is decision would ensure that his parents are financially secure.

Tri, on the other hand, already set her mind on returning to Pontianak after finishing her program in Pharmacy. This was in accordance with her parents' expectations that she would return to Pontianak to become a pharmacist. So, she continued her studies to become a legal pharmacist, as her four-year program did not come with a certificate to practice as a pharmacist. Although at first, she did not want to comply with her parents' wishes to apply for the civil service, she finally applied to make her parents happy. She did not have any hopes to pass the test, since she knew that the competition to enter the civil service is tight. Unexpectedly, she was accepted as a pharmacist at a local state hospital.

She had two jobs, at the hospital and the pharmacy, for six months, before she decided to stop working at the pharmacy and focused on her job at the hospital. She found new ways of contributing to society at the state hospital, as she engaged with patients from remote areas. She was passionate about transferring the knowledge she had to the people, though it was also quite challenging. She felt that she had fulfilled her parents' dream of entering the civil service, and at the same time, managed to fulfil her own aspirations. She continues to take pride in balancing between her own aspiration and her family's. As a way of giving back to her parents, not only does she send part of her income to her family, she also makes sure that her younger siblings are taken care of.

As the eldest in the family, I have to make sure that my younger sister and brother do not go astray. I don't like the

${ }^{5} \mathrm{~S} 1$ is a full four-year university degree program. 


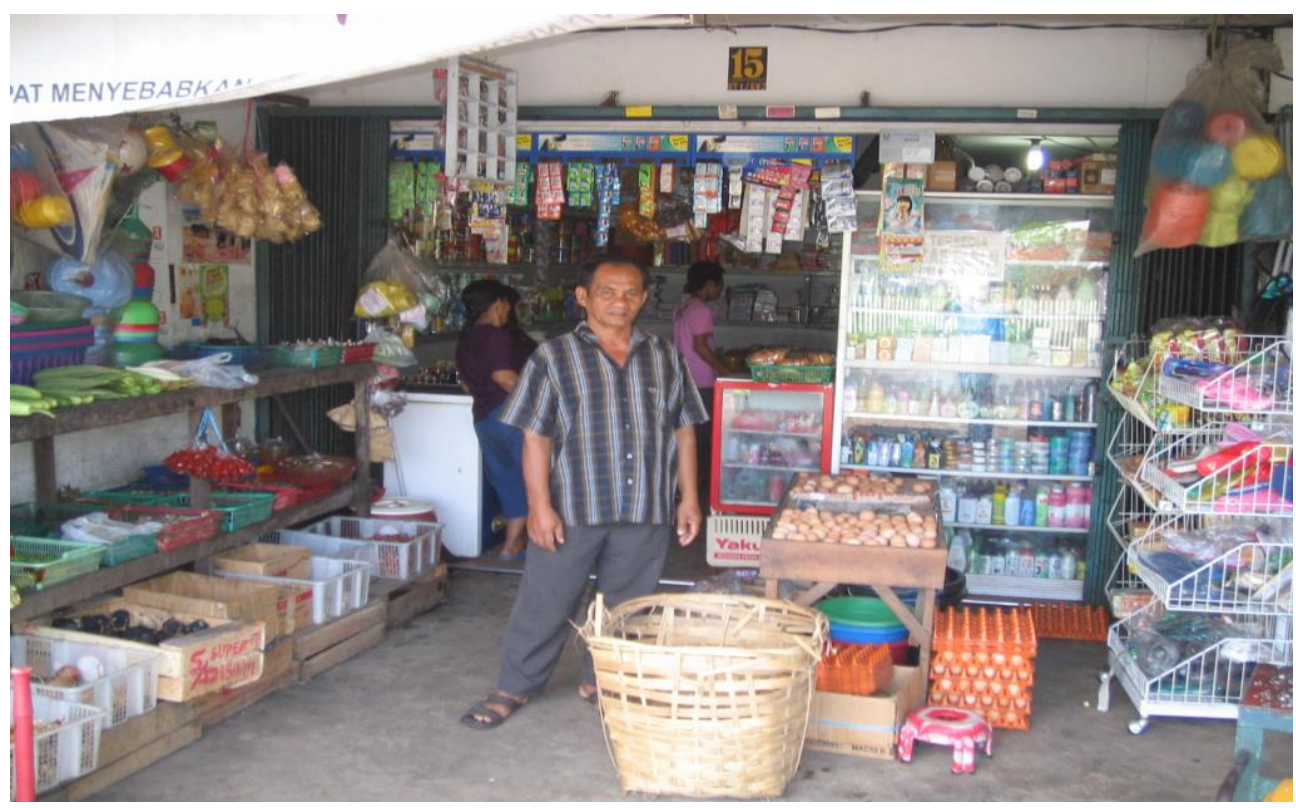

Figure 1. Arjan's Father in Front of The Expanded Family-Owned Shop

way young people are being drawn into a consumerist lifestyle. Even my younger brother is ashamed of taking a bike to school. He would rather walk if I use his motorcycle, because taking a bike is associated with being poor. My parents expect me to train my younger siblings to work hard to achieve their life goals. This is the least I could do for them, since I can't take care of them directly.

\section{Discussion}

The results above show the significance of migration for young people as a pathway to adulthood. Independency is often stated as a marker for adulthood, and many young people believe that migration can facilitate them in achieving that marker. Young people negotiating their way to migrate to Java tend to submit to their parents' wishes to stay behind when both parents object to the idea of migration. Having the support of at least one parent improves a young person's bargaining power to leave. Values parents socialise to their children also influence their migratory decisions, as shown in Tri's case. However, these values are often ambiguous, and young people have to construct how these values are translated in various situations. For example, the message Tri' parents taught of "not selling one's religion" is a general message, that serves as a cognitive schema in dealing with real life situations and processes of adaptation (Koenig, 1995). Using this cognitive schema, Tri constructed her own boundaries of religious tolerance in facing the dilemma between keeping her educational aspiration at the cost of her religious principles, or looking for other channels to realise her aspirations.

Apart from influencing decisionmaking processes to migrate, parents also play an important role in young people's decision to stay or to return to Pontianak. This was apparent in many of the cases, where young people who have already migrated are expected to return to Pontianak, despite having settled into a job at their new place. Caring for the elders are common reasons to persuade children to return. Mothers are usually the ones sending the message to their children to 
return for reasons of caring, since caring is often related to duties borne by the female members of the household. However, when reasons for parents to ask their children to return are reasons related to the public sphere (such as taking care of family business), fathers take the lead in making the decision of whether their children are to return or to continue staying - as illustrated in Arjan's story. His case strongly shows that fulfilling one's own aspiration is important, but being able to balance between fulfilling one's own aspiration and placing it as part of a family project (Asis, 2002) is even more important for young people in their course of migration. This is similar to Yeoh et al (2002), stating that in Asian families, the goal of migration is twofold - to strengthen the family, and to escape the traditional structures of the family. While these two motivations can be seen as two separate entities, it is not necessarily so. These two motivations may go hand in hand, placing relations of interdependence (Minza, 2014) as the foundation of social relations within the family. As such, parental expectations often frame young people's perspective on migration and their migratory experience.

As in many studies on migration (e.g. Curan \& Saguy, 2001; Hugo, 1981; Tukiran, 1986), social network at the place of destination is usually the main consideration in choosing the migration destination. In Tri's case above, family and ethnic network at the place of destination played a significant role in her process of migration. Yet, not all young people have these types of social networks, and they learn to be independent largely on their own. Arjan's story is quite the opposite of Tri's. He had to face various obstacles when he started his education in Yogyakarta. Class origins of the family influence the social networks young people are able to access (Scott, 2006; Curan \& Saguy, 2001). Different from Tri who comes from a middle-class background, Arjan's family had experienced social economic marginality due their low education levels and their status as a defeated ethnic group. Thus, they were not capable of introducing him to their networks in Yogyakarta.

\section{Conclusions}

Migration can be a platform for young people who want to explore horizons beyond the familiarity of their own homes - some succeeded while others fail. Those who fail to negotiate their aspirations with parents, eventually internalise their parents' values and rationalise their failure as part of their dedication to their parents. While some may view young people, who stay behind as part of the immobile society, often seen through a negative lens (Swartz, 2011), these cases show that staying behind is part of young people's strategy to adapt to familial circumstances. For young people from provincial towns, migration becomes one of significant processes to enable them to take part in city life, including obtaining better education. This paper has shown how migration processes are central to understanding social reproduction. Rather than seeing social reproduction as a static state by merely focusing on changes in intergenerational social economic status, it has illustrated the various intergenerational negotiation processes in social reproduction. As such, it also supports the notion that young people do not reproduce in whole the previous generations' values and ways. Young people reshape the values and practices of their parents to fit their own individual aspirations and the social changes they face.

This study has also found that migration is not an individual decision and 
parents play an important role in migratory processes, where the gender of the parent and child matters in both decision making and the realisation of aspirations to migrate. The values parents transfer to their children often serve as a cognitive schema which becomes a resource young people draw upon in making migratory decisions. In places where ethno-religious backgrounds matter, parents' ethnicity and religion either supports or inhibit migratory aspirations. The notion of migrating as a rite of passage to enter adulthood through ideas of becoming independent is evident in many of the young people's narratives, but even more so for those from marginal backgrounds. In the end, however, the full circle to adulthood is embedded in parental expectations of building interdependent relations with the family.

\section{Recommendation}

Educational institutions need to be aware of young migrants' needs, as they come with different sorts and levels of resources from their place of origin. Those with relatively limited resources may find difficulty in making a smooth education to work transition. In this situation, support from educational institutions in the place of destination is much needed.

Acknowledgement on the importance of interdependent modes of parent-child relationship (including responsibilities in caring for parents and providing financial support) means that mobility may be restricted for some. This calls for the need to establish higher quality tertiary education institutions in peripheral locations, which are better integrated with the labour market.

\section{References}

Argent, N., \& Walmsley, J. (2008). Rural youth migration trends in Australia: An overview of recent trends and two inland case studies. Geographical Research, 46(2), 139-152. http://doi.org/10.1111/j.17455871.2008. 00505.x

Asis, M. M. B. (2002) From the life stories of Filipino women: Personal and family agendas in migration. Asia and Pacific Migration Journal, 11(1), 67-93. http://doi.org/10.1177/01171968020110 $\underline{0104}$

Cameron, L. (2003). Growth with or without equity: The distributional impact of Indonesian development. Asian Pacific Economic Literature, 16(2), 1-17. $\quad$ http://doi.org/10.1111/1467$\underline{8411.00119}$

Central Bureau of Statistics. (2010). Data dan informasi kemiskinan kabupaten/kota 2010 (Data and information on poverty in districts/municipalities 2010). Jakarta: Central Bureau of Statistics.

Curan, S. R., \& Saguy, A. C. (2001). Migration and cultural change: A role for gender and social networks? Journal of International Women's Studies, 2(3), 54-77.

Davidson, A. (2014, June 20). It's Official: The Boomerang Kids Won't Leave. Diunduh dari: http://www.nytimes. com/2014/06/22/magazine/its-officialthe-boomerang-kids-wontleave.html?_r=0 tanggal 13 Juli 2015.

Dette, D., \& Dalbert, C. (2005). Moving for their first job or staying put? predictors of high school students' attitudes toward geographic mobility. Journal of Applied Social Psychology, 35(8), 17191737. 
http://doi.org/10.1111/j.15591816.2005.t b02192.x

Effendi, T. N. (2015). Migrasi desa-kota, peluang kerja dan kesejahteraan migran di kota (Rural to urban migration, employment opportunities and migrants' well being in the city). Development, Migration, and Policy Seminar, 2 April 2015. Yogyakarta: Center for Population and Policy Studies, Gadjah Mada University.

Government of Pontianak. (2009a). Sejarah pemerintahan kota (History of city government). Diunduh dari: http:// www.pontianakkota.go.id/?q=tentang/ sejarah-pemerintahan-kota tanggal 20 April 2013.

Heidhues, M. S. (2003). Golddiggers, farmers, and traders in the 'Chinese Districts' of West Kalimantan Indonesia. Ithaca, N.Y.: Cornell University.

Hugo, G. (1981). Village-community ties, village norms, and ethnic and social networks: A review of evidence from the Third World'. Dalam G. D. Jong, \& R. Gardner (Eds.), Migration decision making: multidisciplinary approaches to microlevel studies in developed and developing countries (hlm. 186-224). New York: Pergamon Press.

Jeffrey, C. (2010). Timepass: Youth, class, and the politics of waiting in India. Stanford, California: Stanford University Press.

Kins, E., Beyers, W., Soenens, B., \& Vansteenkiste, M. (2009). Patterns of homeleaving and subjective well-being in emerging adulthood: The role of motivational processes and parental autonomy support. Developmental Psychology, 45(5), 1416-1429. doi: 10. 1037/a0015580.

Koenig, H. G. (1995). Religion as cognitive schema. The International Journal for the Psychology of Religion, 5(1), 31-37. http://doi.org/10.1207/s15327582ijpr050 14

Leksana, G. (2009, January-March). The Betawi brotherhood forum in Indonesia: Struggling to be young and to belong. Inside Indonesia, 95.

Mannheim, K. (1952). The generation problem. In Essays in the Sociology of Knowledge (hlm. 286-322). New York: Oxford University Press.

Mathews, G., \& White, B. (2004). Japan's changing generations: Are young people creating a new society? Oxon: Routledge

Minza, W. M. (2012). Young migrants and education to work transitions in Pontianak, West Kalimantan. The Asia Pacific Journal of Anthropology,13(1), 6475.

Minza, W. M. (2014). Ethnicity and young people's work aspiration in Pontianak. In search of middle Indonesia: Middle classes in provincial towns. Leiden: Brill.

Minza, W. M. (2014). Growing up and being young in an Indonesian provincial town. Amsterdam: University of Amsterdam (Dissertation)

Pontianak Regional Development Agency, (2015). Sekilas profil kota Pontianak (General profile of Pontianak). Diunduh dari: http://bappeda.pontianakkota. go.id/index.php/statistikmenu/beritaa-datastapel/255-sekilas-profil-kotapontianak-kondisi-sampai-denganakhir-tahun-2014 tanggal 24 Juni 2015.

Pontianak Statistics Bureau. (1998). Pontianak dalam angka (Pontianak in figures). Pontianak: Pontianak Statistics Bureau.

Pontianak Statistics Bureau. (2008). Pontianak in figures 2008. Pontianak: Pontianak Statistics Bureau.

Scott, S. (2006). The social morphology of skilled migration: The case of the British Middle Class in Paris. Journal of 
Ethnic and Migration Studies, 32(7), 1105-1129. $\quad$ http://doi.org/10.1080/ $\underline{13691830600821802}$

Seiffge-Krenke, I. (2009). Leaving home patterns in emerging adulthood. European Psychologist, 14(3), 238-248. http://doi.org/10.1027/10169040.14.3.23 $\underline{8}$

Sudagung, H. S. (2001). Mengurai pertikaian etnis: Migrasi swakarsa etnis Madura ke Kalimantan Barat (Disentangling ethnic conflict: Madurese voluntary migration to West Kalimantan). Jakarta: ISAI

Swartz, R. (2011). Immobile Europe. Diunduh dari: http://www. voxeurop.eu/en/content/article/969111 -immobile-europe tanggal 13 Juli 2015.

Tangkilisan, Y. B. (2005). Kerajaan Sintang 1822-1855: Dinamika internal, ekspansi kolonial dan persaingan internasional (Sintang Kingdom 1822-1855: Internal dynamics, colonial expansion, and international rivalry). In J. Gunawan, et al. (Eds.), Desentralisasi, globalisasi, dan demokrasi lokal. Jakarta: LP3ES.

Tukiran. (1986). Population mobility and migrant-village ties. Canberra: MA Thesis, Australian National Unversity.

Wyn, J., \& Woodman, D. (2006). Generation, youth and social change in Australia. Journal of Youth Studies, 9(5). http://doi.org/10.1080/1367626060080 $\underline{5713}$

Williams, S. \& Williams, L. (2005). Space invaders: The negotiation of teenage boundaries through the mobile phone. The Sociological Review, 53(2), 314-331. http://doi.org/10.1111/j.1467954X.2005.00516.X

Yeoh, B. S. A., Graham, E., Boyle, P. J. (2002). Migrations and family relations in the Asia Pacific region. Asian and Pacific Migration Journal, 11(1), 1-11. 